\title{
HIGH SCHOOL ATHLETIC DIRECTORS PERCEPTIONS OF ATHLETIC TRAINER'S PROFESSIONAL KNOWLEDGE AND COMPETENCE BASED ON ATTIRE
}

\author{
A Thesis \\ presented to \\ the Faculty of California Polytechnic State University, \\ San Luis Obispo
}

In Partial Fulfillment

of the Requirements for the Degree

Master of Science in Kinesiology

by

Raechel Nicole Cunningham

June 2013 
(C) 2013

Raechel Nicole Cunningham

ALL RIGHTS RESERVED 


\section{COMMITTEE MEMBERSHIP}

TITLE:

AUTHOR:

DATE SUBMITTED:

COMMITTE CHAIR: $\quad$ Kellie Green Hall, Ph.D.

Professor, Department of Kinesiology

COMMITTEE MEMBER: Camille P. O’Bryant, Ph.D.

Professor, Department of Kinesiology

COMMITTEE MEMBER: $\quad$ Pat Hosegood Martin, Ed.D.

Associate Human Resources Director

Department of Human Resources 


\section{ABSTRACT \\ High School Athletic Directors Perceptions of Athletic Trainer's Professional Knowledge and Competence Based on Attire \\ Raechel Nicole Cunningham}

Very little research is available to identify how attire in the athletic training field impacts perceptions of professional knowledge and competence. The purpose of this study was to identify the effect of attire on high school athletic directors' perceptions of an athletic trainer's professional knowledge and competence. The researcher emailed a questionnaire to ninety-four high school athletic directors from the state of California. The questionnaire measured the effect of attire on the perceptions of skills, knowledge, approachability, experience, education level, overall competence, and representation of an athletic trainer and focused on the difference between khaki attire, professional attire, and workout attire in relationship to perceived knowledge and competence. The respondents rated khaki attire highest followed by professional attire and workout attire when evaluating skills, approachability, overall competence, experience, and knowledge. Representation and education level rated khaki attire as the highest, followed by professional attire, and workout attire rated the lowest. These results indicate khaki attire as the most appropriate attire for high school athletic trainers to wear to achieve the highest perceptions of competence and knowledge from high school athletic directors. 


\section{TABLE OF CONTENTS}

\section{Page}

LIST OF TABLES vii

\section{CHAPTER}

I. INTRODUCTION 1

$\begin{array}{lr}\text { Background of the Study } & 1\end{array}$

$\begin{array}{lr}\text { Purpose } & 5\end{array}$

Research Question 5

Research Hypothesis 5

$\begin{array}{ll}\text { Null Hypothesis } & 5\end{array}$

Significance of the Study $\quad 5$

$\begin{array}{ll}\text { Assumptions } & 6\end{array}$

$\begin{array}{ll}\text { Operational Definitions } & 6\end{array}$

$\begin{array}{ll}\text { Dependent Measures } & 7\end{array}$

II. LITERATURE REVIEW 8

Emergence of Athletic Training in the $20^{\text {th }}$ Century 8

Attire and its Effects on Professionalism and Perception 9

$\begin{array}{ll}\text { Research Pertaining to Physicians and Nurses } & 11\end{array}$

$\begin{array}{ll}\text { Educators and Attire } & 13\end{array}$

The Image of the Athletic Trainer 15

$\begin{array}{ll}\text { Summary } & 16\end{array}$

$\begin{array}{lll}\text { III. METHODOLOGY } & 17\end{array}$

$\begin{array}{ll}\text { Subjects } & 17\end{array}$

$\begin{array}{lr}\text { Instrumentation } & 18\end{array}$

$\begin{array}{ll}\text { Procedure } & 18\end{array}$

$\begin{array}{lll}\text { IV. } & \text { RESULTS } & 20\end{array}$ 
Skills

Approachability

25

Education

25

Overall Competence

26

Experience

27

Representation

27

Knowledge

28

V. DISCUSSION

30

REFERENCES

34

APPENDICES

39

A. Human Subjects 39

B. Questionnaire 40 


\section{LIST OF TABLES}

Table

Page

4.1 Responded Education Level

4.2 Respondent Time in current position 22

$\begin{array}{lll}4.3 & \text { Contract Type } & 23\end{array}$

4.4 Characteristic Mean Scores \& Standard Deviation 24

4.5 Skills Mean Scores \& Standard Deviation 24

4.6 Approachability Mean Scores \& Standard Deviation 25

4.7 Education Mean Scores \& Standard Deviation 25

4.8 Overall Competence Mean Scores \& Standard Deviation 26

4.9 Experience Mean Scores \& Standard Deviation 27

4.10 Representation Mean Scores \& Standard Deviation 28

4.11 Knowledge Mean Scores \& Standard Deviation 28

4.12 Appropriate Attire Based on Coverage 29 


\section{Introduction}

\section{Background of the Study}

Proper attire is an integral aspect of one’s professional success. The clothes a person wears to work sends a message about how the person values their position and reflects the nature of the employment. While codes of dress are quite established in many professions the unique job description and dynamic responsibilities of a certified athletic trainer (ATC) leave the proper attire for this profession less clear. First, in addition to a typical office setting, an athletic trainer will also be called upon in a range of venues, including the field, the gym, the track, and even the pool deck. As the first medical responders for athletes in practice and competition settings, the physical demands on an ATC may include swift movement, bending, reaching, and the carrying of equipment. An ATC must interact with athletes who are wet, sweating or bleeding and may be required to exert force to effectively diagnose or treat injuries. These responsibilities necessitate clothing and shoes that allow the athletic trainer to move comfortably and without restriction for sustained periods of time.

Over the past three decades, athletic trainers' informal code of dress generally includes gym shorts and t-shirts for practices and khaki shorts or pants with a polo shirt for outdoor competitions and the general coverage of the athletic training room. Indoor competition attire is typically more professional including dress slacks and button up shirts for men and dress pants and a blouse for women (Eaves, 2009, p 11). While most athletic trainers adhere to these informal practices, there are no stated guidelines that are endorsed by the profession. Although certified athletic trainers are widely respected as medical professionals in the athletic community, policy makers and the general public are less familiar with the specialized expertise of the field and the rigorous educational certifications required to become an ATC. 
In recent years, this lack of familiarity has become increasingly problematic as the list of acceptably billable health services, especially within Medicare and Medicaid, has become more limited. Most significantly, in June of 2005, athletic training and its professional skill set were challenged when Title XVIII of the Social Security Act was passed (U.S. Department of Health and Human Services, 2007). Under this new rule; doctors are not able to bill Medicare for treatment provided by athletic trainers. Marjorie Albohm, MS, ATC, the current President of the National Athletic Training Association (NATA), stated “...the rule incorrectly implies that athletic trainers are not trained to provide rehabilitation services and will affect every ATC in every practice setting, and if that's not overturned, it will be used against us as we go forward" (NATA, 2005).

In 2006 and again in 2009 the NATA introduced The Athletic Trainers’ Equal Access to Medicare Act (ATEAM, H.R. 1137) into the House of Representatives to amend title XVIII of the Social Security Act. This bill sought to "amend access to outpatient occupational and physical therapy services provided incident to a physician's professional services if furnished by an educated or credentialed therapist who does not have a license; and coverage of certified athletic trainer services under part B (Supplementary Medical Insurance) of Medicare” (http://www.govtrack.us/congress/bills/111/hr1137). In 2011 H.R. 1137 was reintroduced by congressman Edoplphys Towns, as H.R. 2785 and is currently being reviewed by the house committee on energy and commerce and the house committee on ways and means http://www.govtrack.us/congress/bills/112/hr2785. H.R. 2785 would improve patient access by allowing physicians to recognize athletic trainers as qualified healthcare providers under Centers for Medicare and Medicaid Services (CMS) and utilize athletic trainers and other 
qualified healthcare professionals (NATA, 2012). The NATA continues to dedicate resources to pass H.R. 2785 and continues to look for co-sponsors (NATA, 2012)

With these pending changes in legislation the image of an athletic trainer continues to grow in importance. Is a certified athletic trainer simply a glorified personal trainer or coaches' aid, or a respected and well educated member of the allied health care profession? Furthermore, does the image and attire of an athletic trainer reflect knowledge and competence to those in the allied health care profession and administrators within their department?

Advancements in education and legislation, along with continued efforts by the NATA to improve the image of the athletic trainer all may help validate the profession. The most drastic change has been the shift from an internship based athletic training education to the accreditation of all athletic training educational programs by the Commission on Accreditation of Athletic Training Education (CAATE). The NATA has also worked diligently to pass fair practice laws and licensure, as well as develop recommendations to all levels of athletics to help provide quality health care to those populations that would benefit from an athletic trainers' unique skill set. Even with these changes the professional image and recognition of an athletic trainer is still not consistent with other allied health care professions (Dodge \& Mensch 2004).

Researchers within the medical and educational communities have examined the impact attire has on patient and student perceptions. Medical professionals have shown a relationship between professional attire and a positive patient perception. This positive perception results in increased confidence, patient preference, and support (Brase \& Richmond 2004). Researchers within the nursing profession showed a decrease in a patients perception of authority and approachability with more casual dress (Miller, Mann, \& Grim, 2010). Educators recognized that students have a higher opinion of their education when their instructor is dressed in 
professional attire (Carr, Davies, Lavin, 2010). If similar relationships exist between attire and administrators' perceptions, athletic trainers could see a positive influence in confidence and authority and more respect among other allied health professionals with more professional attire.

Mike West, MS, ATC and David Jessup, MS, ATC have expressed opinions in the publication NATANews regarding the professional image and practice that athletic trainers' exhibit while they are in their respective settings. Wests' opinion is that athletic trainers' should wear appropriate attire within the athletic training room and at all athletic contests. This would eliminate t-shirts and gym shorts, and should present a greater professional image (West, 2004). Jessup argues that professionalism is based on how ATC's apply the professional skills and knowledge that have been gained through education and experience, not on outward appearance and attire. Professional practice and appropriate knowledge and behavior will convey professional image (Jessup, 2004).

The Board of Certification Standards of Professional Practice as well as the NATA code of ethics does not provide guidelines for appropriate attire for a practicing athletic trainer; however researchers in other allied health professions have suggested that attire can influence the perceptions of knowledge and competence. Understanding how attire influences perceptions will help to develop recommendations for the most professional image. If attire does influence the perceptions of an athletic trainers' knowledge and competence, then it would be necessary to evaluate the attire athletic trainers choose. However, if attire does not effect the perception of knowledge and competence, then ATCs may no longer need to be concerned with its effect on professional image. 


\section{Purpose}

The purpose of this study was to investigate the effect of attire on high school athletic directors’ perceptions of an athletic trainer’s professional competence and knowledge.

\section{Research Question}

Does a high school athletic directors perceptions of an athletic trainers professional competence and knowledge increase when an athletic trainer is dressed more professionally.

\section{Research Hypothesis}

Casual attire will decrease a high school athletic director's perception of an athletic trainer's professional competence and knowledge.

Professional attire will increase a high school athletic director's perception of an athletic trainer's professional competence and knowledge.

\section{Null Hypothesis}

Attire will have no impact on high school athletic directors’ perceptions of athletic trainers; professional competence and knowledge.

\section{Significance of the Study}

Low salary, limited positions, and low budgets are a common issue. If athletic trainers seek to improve on the current situation at most high schools it is imperative to be perceived as an irreplaceable professional and competent health care provider. The athletic director is the person who has the responsibility of hiring and firing within the department, determining the 
needs of the athletic department, and is the administrative support for budget and employment. Athletic trainers should be perceived by high school athletic directors as valued and irreplaceable members of the health care staff. In all allied health professions and education research has shown that attire plays a major role in helping shape perceptions; however, in the case of athletic training, there is a lack of clarity as to which attire is most effective in conveying athletic trainers’ competence and knowledge to athletic directors.

\section{Assumptions}

Three assumptions guide this investigation. They are as follows:

1. All participants have an understanding of the job descriptions and requirements of a certified athletic trainer.

2. Participants are in direct contact with the athletic trainer all or many days of the week throughout the school year.

3. Participants are the direct supervisor of the athletic trainer.

\section{Operational Definitions}

Attire- The exterior garments an individual chooses to wear including, pants, shoes, and shirts.

Perceptions- Identification, professional ability, and approachability

Competence and Knowledge- The knowledge and education required of a person to become a certified athletic trainer.

Certified Athletic Trainer (ATC )- A person who graduated from an institution accredited by Commission on Accreditation of Athletic Training Education (CAATE) or 
completed an approved internship education, has passed the National Athletic Training Association Board of Certification (NATABOC) exam and maintained current continuing education units (CEU’s).

Competencies- Risk management, injury prevention, pathology, acute care, assessment and evaluation of injuries and illnesses, pharmacology, therapeutic modalities, therapeutic exercise, general medical conditions and disabilities, nutritional aspects of injury and illness, psychosocial intervention and referral, health care administration, and professional development and responsibilities (Prentice, 2003).

\section{Dependent Measures}

The questionnaire the researcher developed for this study identified perceived professional knowledge and perceived competence of athletic trainers. The researcher wanted to addressed high school athletic directors’ perceptions of competence, education, knowledge, experience, skill and approachability as well as identify specific opinions about attire as related to different parts of an athletic trainer’s occupational expectations. 


\section{Literature Review}

The purpose of this study was to investigate the effect of attire on high school athletic directors' perceptions of an athletic trainer's professional competence and knowledge. This review examines the history of athletic training and helps to identify and assess previous research into the impact attire has on professional knowledge and competence. Very little research has been conducted examining attire in the athletic training field; however an emphasis on nurses, physicians, and educators’ research was examined. Researchers within these related fields have addressed how attire affects perceptions of knowledge and competence.

\section{Emergence of Athletic Training in the $20^{\text {th }}$ Century}

The first athletic trainers are believed to have been seen in ancient Greek and Roman civilizations during the Pan Hellenic Games, a predecessor of the Olympic Games. The

profession that we now call athletic training emerged around the early $20^{\text {th }}$ century where athletic trainers were seen mostly in intercollegiate settings (Prentice, 2003). Athletic trainers are now employed in almost every setting that involves physical activity including high schools, professional sports, industrial settings, health and fitness organizations, NASA, performing arts, and educational institutions (Hillman, 2000).

In the early 1950’s a group of intercollegiate athletic trainers developed the National Athletic Trainer's Association (NATA) to establish professional standards and create an organizational structure for the profession. In 1974, the first time membership numbers were tracked, there were 4,500 members. Today the NATA has grown to over 32,000 certified and 
student members. The NATA has helped to unify athletic trainers by setting a standard for professionalism, education, certification, research and practice settings (Prentice, 2011).

The American Medical Association (AMA) recognized athletic training as an allied health profession in June of 1990. At this time the NATA Board of Certification (NATABOC) altered athletic training curriculum to conform to the AMA's Committee on Allied Health and Education and Accreditation suggestions (Ebel, 1999). In 1999, the NATA performed a Role Delineation Study and identified changes that needed to be made to athletic training education. Starting in 2000, The NATA and the BOC transitioned athletic training education from an internship model program to a formal curriculum program utilizing a competency-based model.

In 1970 the NATABOC saw a need to administer a standardized certification exam. Initially the exam was three sections, with two sections to focus on the oral/practical competence, and the third, a multiple choice section (NATABOC, 2007). Not long after the education model shifted in 2000, the NATABOC examinations began to change as well. Starting in 2007, to be more aligned with other allied health professions, the exam shifted to a completely computer based exam, which is the current model being used. In order to become a certified athletic trainer one must graduate from a Commission on Accreditation of Athletic Training Education (CAATE) program and pass the NATABOC certification exam, to maintain certification one must obtain and report 75 continuing education units every three years.

\section{Attire and its Effects on Professionalism and Perception}

In an article entitled the “A's and B's” of Professionalism Hammer (2000) developed and defined professional attitudes and behaviors. This helped to develop a more all-inclusive understanding of professionalism relating to pharmaceutical students, faculty members, and other 
related personnel. The researcher defined professional attitudes as "predisposition, feeling, emotion or thought that upholds the ideas of a profession.” Professional behaviors were defined by the researcher as "behaving in a manner to achieve optimal outcomes in professional tasks and interactions” (Hammer, 2000). Components of professional attitudes and behaviors that were provided are long and detailed. For the purpose of this study, the professional attitude of respect with the corresponding professional behaviors of appropriate dress, punctuality, and the ability to maintain confidentiality were most important (Hammer, 2000). Understanding that attire is a professional behavior, the researcher is able to identify a need for further exploration into the types of attire that may portray athletic trainers in the most positive and professional way.

In past years Vruggink and Green (2002), Jessup (2004), West (2004), Mensch (2005), and Dodge and Mensch (2004) have discussed professional attire for athletic trainers in athletic training publications. Attire is a professional behavior that is controlled by each individual but has the potential to impact the entire profession. According to the NATA mission statement “Athletic trainers must be an integral component in shaping the profession's future and understand the principles and obligations associated with being a member of a profession.” (Ray, 2000, p. 138) Dressing professionally is a decision athletic trainers should not undervalue in any allied health care setting (Ray, 2000).

To understand how individuals formed impressions based on attire, Johnson, Schofield and Yurchisin (2002), conducted a study using a free-response interview of 39 women. The interview consisted of eight questions that identified the development of an impression of someone utilizing appearance and attire. The researchers used Q.S.R NUD.IST Software for Qualitative Data Analysis to sort and code the interviews. Responses relating to appearance and 
attire that provided visual and non-visual cues were categorized based on Roach-Higgins and Eicher (1992) and Park (1986) into five categories: character traits, behaviors and activities, attitudes, feelings and beliefs, demographic information and, physical and biological traits.

The researchers found that attire creates non-verbal cues that individuals translate into meaning from another's appearance as well as his or her attire. They also concluded that these impressions were formed unavoidably on an unconscious level. Johnson et al. (2002) noted many documents suggesting that individuals make inferences or form impressions of others on the basis of their attire. The results the researchers obtained suggest that appearance has a large impact on the perceptions of a person specifically based on their choice of attire, and that these perceptions are not always conscious or controllable.

\section{Research Pertaining to Physicians and Nurses}

Allied health professionals have investigated the effect of attire on patient perceptions using various research methods. Lehna, Pfoutz, Peterson, Degner, Grubaugh, Lorenz et al., (1999) conducted interviews to determine how nursing attire influenced the image of the profession. The researchers performed 14 twenty minute interviews of nurses' patients and examined how attire affected perceptions of current nurses and if attire related to their professionalism. They concluded that attire served as a way for the public to identify specific groups and occupations and that it may influence patient behavior as well as affect comfort and approachability. They also found that patients identified nurses easier when the nurse was wearing a uniform and that although other forms of attire were acceptable, patients still preferred traditional white dress. Lehan et al. (1999) concluded that nursing attire becomes vital when it helps the health-care consumer identify the nurse. 
Skorupski and Rea (2006) investigated how nursing attire affected patients perceptions of professionalism and approachability. Respondents included 180 patients that completed a 13item questionnaire which displayed three different nursing uniforms. Using descriptive statistics and analysis of variance the researchers were able to see a relationship between age, attire, professionalism and approachability. Respondents in the senior age range had a higher perception of professionalism and approachability with nurses in white uniform, whereas all other respondents had a higher perception of approachability and professionalism when a nurse wore a uniform with print. Thus, this research suggests that while uniforms help to identify a nurse, generational gaps present a unique problem to identifying which uniforms are most appropriate.

Thomas, Ehret, Ellis, Colon-Shoop, Linton, and Metz (2010) surveyed 240 participants, including nurses, students, patients, and faculty, to investigate the different perceptions of skill and knowledge based on attire and body art. The questionnaire included images of nurses in three different types of attire; solid scrubs, printed scrubs, and T-shirt attire. Using multivariate analyses the researchers identified a higher perception of skills and knowledge when nurses wore solid scrubs as opposed to printed scrubs across all participants. The researchers concluded that in an acute care setting solid colored nurse's uniform result in the highest perception of skill and knowledge.

In addition to nurses, attire has also been shown to affect doctor-patient relationships. Researchers at a Veterans Administration Medical Center conducted a cross-sectional study of 400 patients from January 2003-June 2003 to determine how physicians' attire affected a patient's perception of trust and confidence (Rehman, Nietert, Cope, Lipatric, 2005). Subjects were randomized by the researchers into four different groups and each group was shown four 
photographs of one individual in four different styles of attire which included business attire, professional attire, surgical scrubs, and casual attire. Once the researchers identified the respondents group, they were given a questionnaire and asked to report their preference for each of the four styles of attire. The questionnaire aimed to identify subjects' "trust, confidence, and willingness to share social, sexual, and psychological problems with the physician in each of the pictures” (Rehman, 2005, p.1283).

The researchers performed statistical analysis using chi-squared. They compared responses across age, race, and sex to the race, sex, and attire of the physician. They also used chi-squared to identify which patient factors were significantly associated with the importance patients placed on physician appearance. When the researchers identified a significant preference for professional attire a multivariate logistical regression was performed against patient and physician characteristics to determine which characteristics were independently and significantly associated with the preference for professional attire. They performed the logistical regression at a 95\% confidence interval using odds ratios for summary. The researchers used the logistical regression results to demonstrate a positive relationship between professional attire and patients' perception of quality of care, and higher trust and confidence associated with professional attire. The researchers concluded that attire was not only important but that the subjects showed a greater preference for professional attire followed by surgical attire, business dress, and finally scrubs (Rehman et al. 2005).

\section{Educators and Attire}

Researchers within the education profession have investigated the effect of attire on perceptions of knowledge and competence as well. A study completed by Roach (1997) 
examined the effects of "Graduate Teaching Assistant Attire on Students Learning, Misbehaviors, and Ratings of Instruction.” College students ( $\mathrm{n}=355)$ were asked to rate and provide information regarding the teaching assistant (TA) or instructor of a basic communications class. As soon as the course was completed participants were given a questionnaire. A seven item professional dress assessment instrument was used by students to rate instructor dress based on the following criteria: informal-formal, wrinkled-pressed, inappropriate-appropriate, dirty-clean, professional-nonprofessional, neat-sloppy, fashionablenot fashionable. Students' attitudes towards the course, the instructor and the content were positively affected when an instructor wore more professional attire. The researcher was able to identify a positive correlation ( $\mathrm{p}=.00001$ ) between perceptions of dress and student learning. Researchers performed Analysis of variance and showed significant relationships between professional attire and student cognitive learning, affective learning and rating of instruction.

Morris, Gorham, Cohen, and Huffman (1996) found similar results when measuring perceptions of students at the beginning, midterm, and end of the course. The researchers wanted to investigate the effect of three dress conditions on students' perceptions of college teachers. Four graduate students presented guest lectures in each attire condition (formal professional, casual professional and casual) in three different sections of the course. Following the lecture the subjects completed an evaluation form, indicated their gender and rated the instructor. The perceptions were measured using five-point bipolar descriptors to identify competence, character, sociability, composure, and extroversion. Using ANOVA the researchers concluded that perceptions of competence and knowledge decreased as attire became more casual and was highest in formal professional attire and its relationship to instructor competence. In a follow-up study of similar design corresponding results were found. Instructors who regularly dressed in 
very casual attire when compared to professional attire were rated as less competent (Gorham, Cohen, and Morris, 1999).

\section{The Image of the Athletic Trainer}

Professionalism may change in various settings but there are common themes throughout the profession. According to Carr-Saunders (1966) “A profession may be defined as an occupation based upon specialized intellectual study and training, the purpose of which is to supply skilled service or advice to others for a definite fee or salary (p.310-312).” What makes athletic training a profession is its skill-based theoretical knowledge, training and education, certification, code of ethics, public good, and association (Hillman, 2000, p. 7).

The role of the athletic trainer has continued to evolve along with the philosophy of its members (Hillman, 2000). “To simply accomplish the daily tasks of the job is not enough; athletic trainers will be judged like other allied health care's, and if they do not fulfill their obligations both they and the profession suffer” (Craig, 2006, p.8). Defining appropriate attire for athletic trainers may be an arduous task. There are various levels and settings where one may be employed and operations throughout the work week may require different types of acceptable attire. In the traditional athletic training setting, it is difficult to determine what will happen next and where the athletic trainer may be needed. However, if there was further development of what professional attire is in the athletic training world, perhaps respect from other allied health care professions would follow.

An important difference exists between gaining respect as an individual and gaining respect as a profession. Since athletic trainers are in a profession that is visible by a variety of individuals one must display a professional image at all times, not just at professional meetings 
or conferences. "Most people notice appearance first and dressing appropriately sends a message that athletic trainers take pride in their profession” (Vruggink \& Green, 2002, p.48). Attire is not only a reflection on the individual but the profession as a whole. A professional image at all times will communicate a level of respect for the professional as well as the profession.

Since athletic training is still evolving and continues to emerge in new settings it is important to understand that every impression counts. Ideas that are being formed have the potential to positively or negatively affect the individual and the profession. "Appearance establishes a professional perception: if one looks good one is sure to be good and considering that athletic trainers maintain a high level of training to provide care, perhaps it is time to look like professionals” (Vruggink \& Green, 2002, p.48).

\section{Summary}

Previous scholars have addressed how attire and perceptions are related amongst professionals in the fields of nursing, pharmaceuticals, medical doctors, and educators. Unfortunately there is little research about the relationship between athletic trainers' attire and its impact on professionalism and perceptions among administrators. Based on the literature in other fields there is a clear relationship between professional attire and the perceptions of professional knowledge, skill and competence. What is not clear is if that same relationship exists among athletic trainers, and what attire best demonstrates that relationship. This research was designed to identify if attire, and what type of attire has an impact on administrators, specifically high school athletic directors’ perceptions of professional competence and knowledge. 


\section{Methodology}

Researchers within the related allied health fields of nursing and physicians, and the education profession have investigated the effect attire has on perceptions of knowledge and competence. Roach (1997) acknowledged a significant relationship existed between professional attire and student cognitive learning, affective learning, and rating of instruction. Rehman et al. (2005) showed that patients rated physicians in professional attire with the highest perceptions of quality of care, and trust and confidence. The purpose of this study was to investigate high school athletic directors’ perceptions of an athletic trainer's professional competence and knowledge based on attire.

\section{Subjects}

Ninety-four high school athletic directors (78 male and 18 female) from the state of California volunteered to participate in this study. They ranged in age from 21 to 61 or more years of age ( $\underline{M}=41-45$ years). The researcher randomly selected 603 subjects within the California Interscholastic Federation (CIF) personnel guide using Microsoft Excel’s random selection generator. The subjects were contacted by the researcher via e-mail with a letter addressing the requirements and a survey link. Those who agreed acknowledged the informed consent to participate and implied their consent by continuing to the questionnaire (see appendix A). 


\section{Instrumentation}

The survey instrument the researcher developed to collect data for this study was designed based on the research manuscripts of Rehman et al. (2005) "Doctors attire on Patient Trust,” and Brase \& Richmond (2004) “The white-coat effect.” The questionnaire contained six photos of 3 men and 3 women in three different types of attire. To determine which photos would be used for the questionnaire, ten males and ten females were digitally photographed in three different attires: gym shorts and a t-shirt; khaki’s and polo; and business casual. A friendliness and attractiveness questionnaire was then applied to the photos and those photos with the highest scores were chosen for the final questionnaire (Appendix B). Many of the questions were a 5-point Likert scale following the standards of most important, important, somewhat important, neutral and not important. The questionnaire was designed using www.surveymonkey.com, an online resource for survey design and data collection.

\section{Procedure}

The researcher emailed participants on Tuesday March 2, 2011 at 2pm to avoid the influx of emails many workplaces experience throughout the weekend and early morning attempting to avoid the email getting lost. The email directed participants to an online questionnaire at surveymonkey.com that took no more than 15 minutes to complete. The participants were prompted to complete the questionnaire to the best of their ability and were not required to answer any question. The questionnaire was created to match the research question and was edited by a professional in the field of participants, a professional within the field of athletic trainers, and a professional within the field of survey research. Responses were collected for one month, during that time; the researcher sent a reminder email at the two week mark redirecting 
any participant to surveymonkey.com if they had not already completed the questionnaire. After one month the questionnaire was made inactive on surveymonkey.com. Once all responses were collected the researcher used surveymoney.com to generate a data report. All responses were transferred into minitab worksheets for data analysis. 


\section{Results}

The purpose of this study was to investigate the effect of attire on high school athletic directors’ perceptions of athletic trainers' professional competence and knowledge. Utilizing previous research in the related fields of health care and education it was hypothesized that casual attire would decrease a high school athletic director's perception of an athletic trainer's professional competence and knowledge; also professional attire would increase a high school athletic director's perception of an athletic trainer's professional competence and knowledge.

The dependent measures used to identify professional knowledge and competence were skills, knowledge, approachability, experience, education, overall competence, and representation of an athletic trainer. Each factor was measured using a 5-point likert scale with 5 being the highest level and 1 being the lowest level. The results were analyzed using a general regression analysis to identify if gender had any effect on attire in each dependent measure. One -way analysis of variance (ANOVA) was performed for each dependent measure at an alpha level of .05 with a Tukey’s post-hoc comparison when the analyses reached significance.

There were not enough data points to perform a regression analysis so the researcher was unable to identify the effect of attire on the athletic directors' perceptions. To determine which attire resulted in the highest ratings of knowledge, approachability, experience, education, skills and overall competence the researcher used ANOVA and descriptive statistics. The researcher performed general regression analysis to determine if an interaction existed between the model gender and type of attire. The interaction was reported in relationship to professional skills, professional knowledge, perceived competence, perceived education, and perceived approachability. 
A total of 94 out of 603 (15\% response rate) high school athletic directors responded and completed the questionnaire. The respondent's median age was 43 years old with 78 of them being male and 18 being female. A majority of the respondents held a degree in higher education, one did not report education level, two completed some college, one held an associate degree, 30 held bachelor degrees, 40 held graduate degrees, and 22 held post graduate degrees (Table 4.1) . 16 respondents had held their position 0-3 years, 22 had been at the current position for 4-8 years and 14 respondents held their current position for 9 or more years, the remaining 44 respondents did not indicate how long they had been at their current position (Table 4.2).

Table 4.1

Respondent Education Level

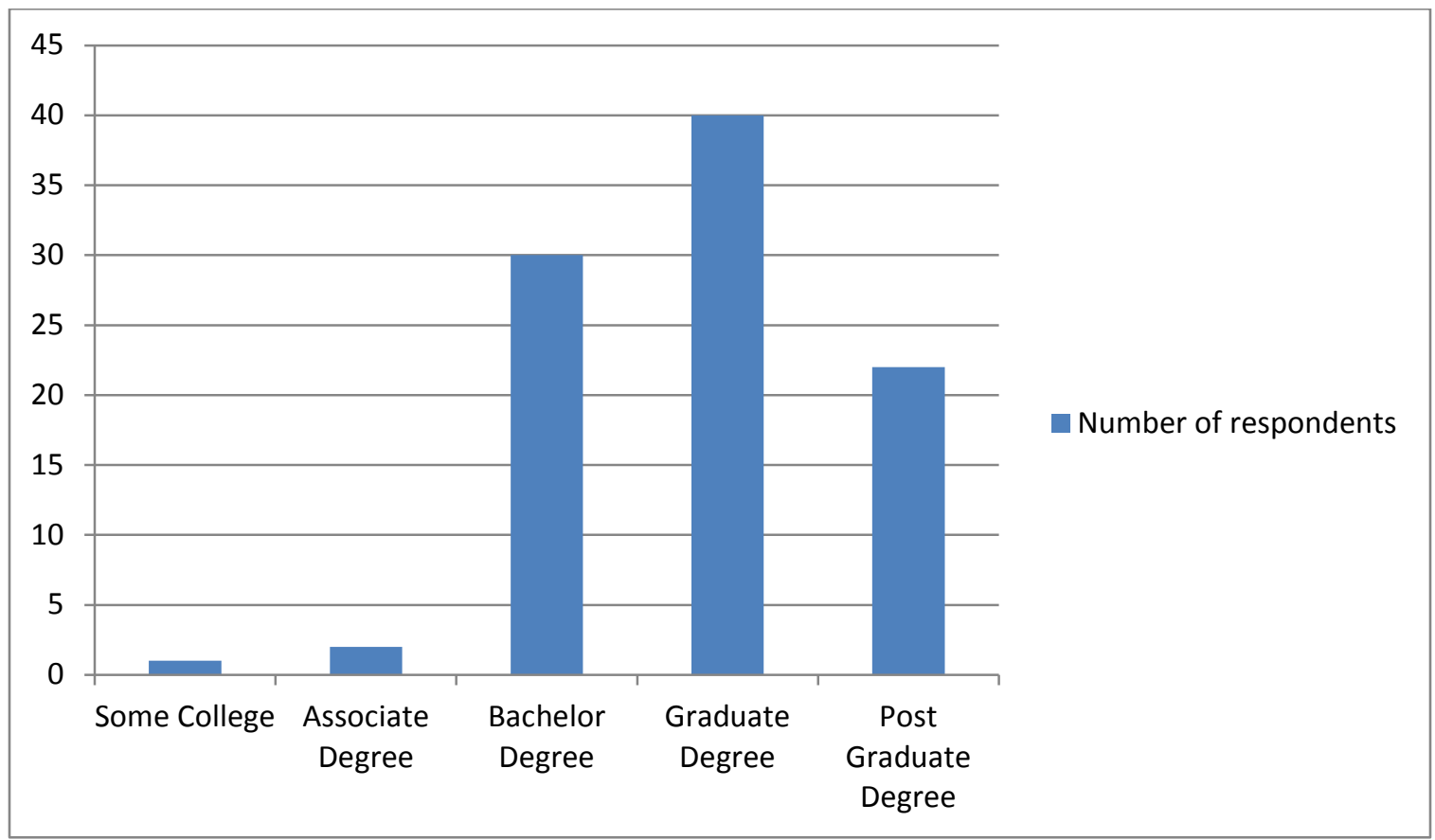


Table 4.2

Respondent Time in current position

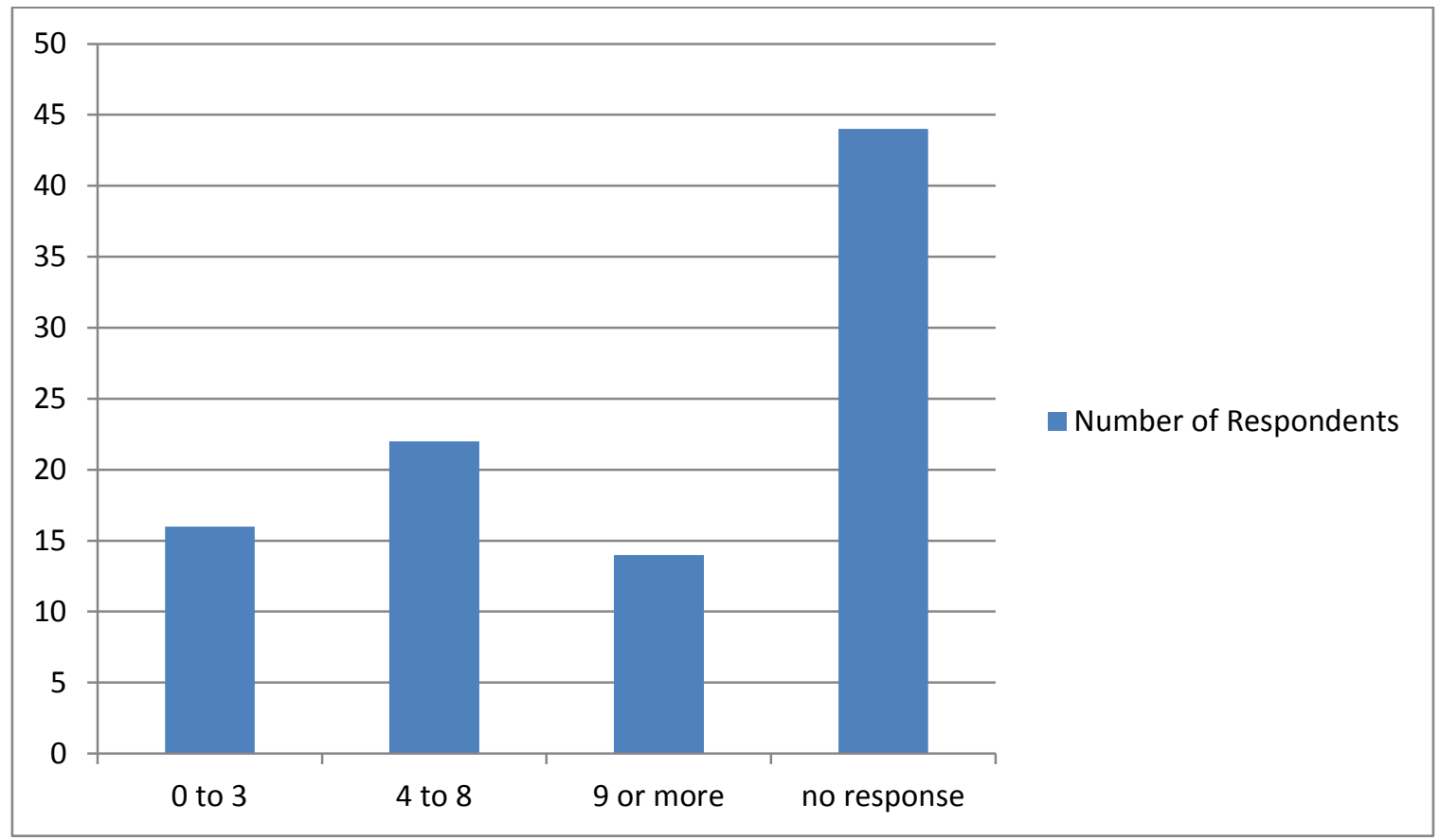

Of all that responded 21 indicated having a full-time athletic trainer employed at their current institution, 11 had a part time athletic trainer, 10 contracted an athletic trainer from another source, and the remaining respondents did not have an athletic trainer in any capacity (Table 4.3). 
Table 4.3

Contract Type

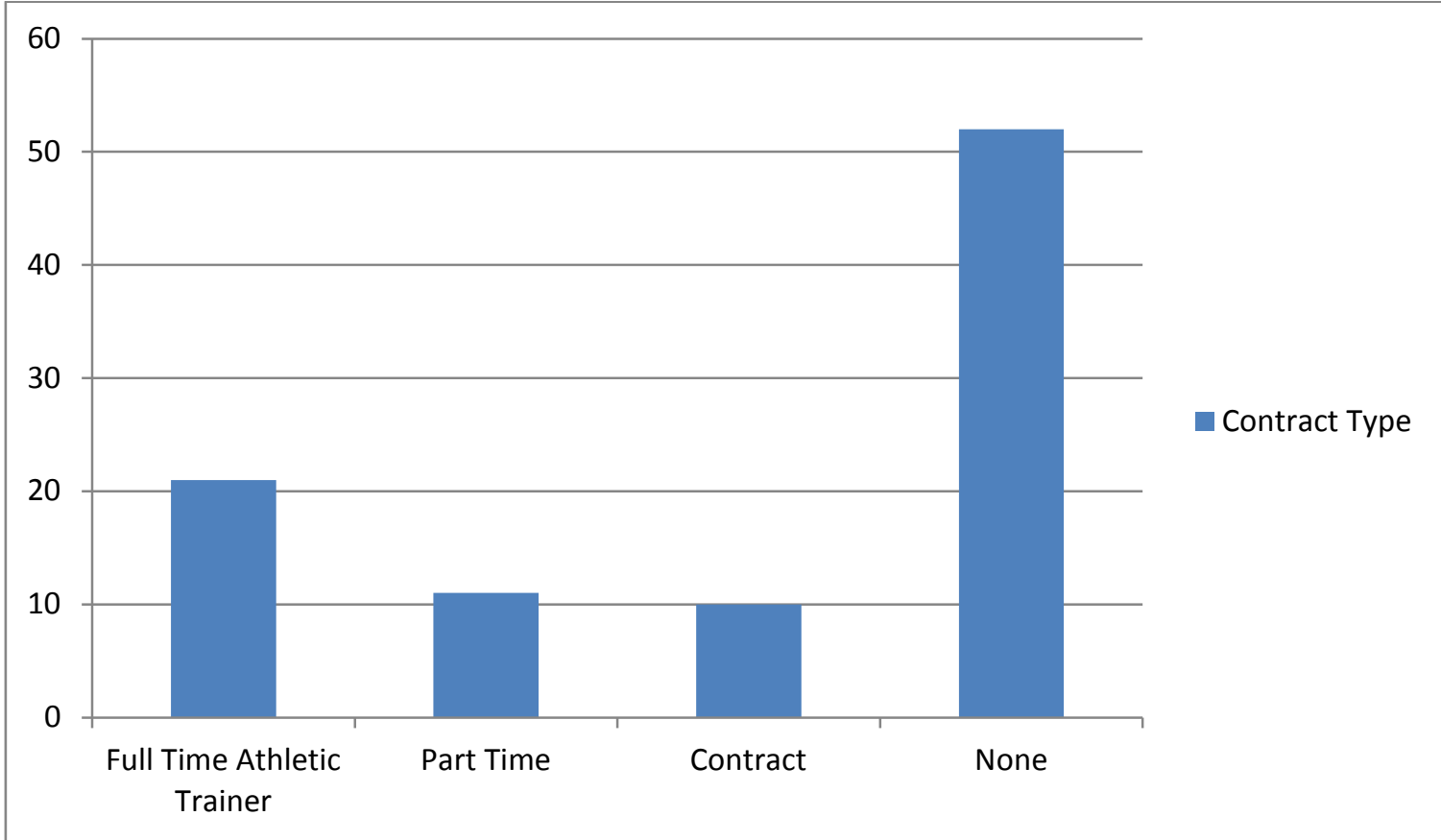

The respondents began the questionnaire by rating the importance of specific attributes an employee and more specifically an athletic trainer should have. Accountability, fair treatment of athletes, punctuality, confidentiality, and organization were all rated as being important characteristics an athletic trainer should posses. Table (4.4) below displays the mean scores for each characteristic. 
Table 4.4

Characteristic Mean Scores\& Standard Deviation

\begin{tabular}{ccc}
\hline Characteristic & Mean Score & Stnd Dev \\
\hline Accountability & 4.443 & 1.568 \\
Fair Treatment & 4.454 & 1.514 \\
Punctuality & 4.216 & 1.798 \\
Confidentiality & 4.371 & 1.609 \\
Organized & 4.000 & 1.995 \\
\hline
\end{tabular}

\section{Skills}

General regression considering Gender and Attire showed $\mathrm{P}=0.349$ indicating no effect of gender. ANOVA showed a significant difference $(F=19.22)$ between the three groups. Table (4.5) shows Khaki having the highest rating and mean score (mean=3.320), followed by professional attire (mean=2.673) and workout attire (mean=2.327) which had no significant difference between each other.

Table 4.5

Skills Mean Scores \& Standard Deviation

\begin{tabular}{ccc}
\hline Attire & Mean Score & Stnd Dev \\
\hline Khaki & 3.320 & 1.416 \\
Professional & 2.673 & 1.402 \\
Workout & 2.327 & 1.407 \\
\hline
\end{tabular}




\section{Approachability}

General regression considering Gender and Attire showed $\mathrm{P}=0.151$ indicating no effect of gender. ANOVA showed a significant difference $(\mathrm{F}=14.43)$ between the three groups as shown in table 4.6 below. Khaki was rated the highest (mean=3.673) followed by professional attire (mean=3.107) and workout attire (mean=2.813) which had no significant difference between each other.

Table 4.6

Approachability Mean Scores \& Standard Deviation

\begin{tabular}{ccc}
\hline Attire & $\begin{array}{c}\text { Mean } \\
\text { Score }\end{array}$ & $\begin{array}{c}\text { Stnd } \\
\text { Dev }\end{array}$ \\
\hline Khaki & 3.673 & 1.308 \\
Professional & 3.107 & 1.489 \\
Workout & 2.183 & 1.425 \\
\hline
\end{tabular}

\section{Education}

General regression considering Gender and Attire showed $\mathrm{P}=0.572$ indicating gender did have an effect on the responses. ANOVA showed a significant effect for the group ( $F=18.92)$. The khaki attire (mean=2.772) rated highest, followed by professional (mean=3.300) and workout attire (mean=2.280) as the lowest. 
Table 4.7

Education Mean Scores \& Standard Deviation

\begin{tabular}{ccc}
\hline Attire & $\begin{array}{l}\text { Mean } \\
\text { Score }\end{array}$ & $\begin{array}{c}\text { Stnd } \\
\text { Dev }\end{array}$ \\
\hline Khaki & 3.300 & 1.473 \\
Professional & 2.772 & 1.471 \\
Workout & 2.280 & 1.362 \\
\hline
\end{tabular}

\section{Overall Competence}

General regression considering Gender and Attire showed $\mathrm{P}=0.531$ indicating gender did have an effect on the responses. ANOVA showed a significant difference $(F=20.89)$ between the three groups with Khaki having the highest mean score (mean=3.340). Professional attire (mean=2.620) and workout attire (mean=2.300) were not statistically different.

Table 4.8

Overall Competence Mean Scores \& Standard Deviation

\begin{tabular}{ccc}
\hline Attire & $\begin{array}{c}\text { Mean } \\
\text { Score }\end{array}$ & $\begin{array}{c}\text { Stnd } \\
\text { Dev }\end{array}$ \\
\hline Khaki & 3.340 & 1.451 \\
Professional & 2.620 & 1.427 \\
Workout & 2.300 & 1.403 \\
\hline
\end{tabular}




\section{Experience}

General regression considering Gender and Attire showed $\mathrm{P}=0.892$ indicating an effect of gender on attire. ANOVA showed a significant difference $(\mathrm{F}=25.41)$ between the three groups with Khaki having the highest mean score (mean=3.273). Professional attire (mean=2.440) and workout attire (mean=2.180) were not statistically different.

Table 4.9

Experience Mean Scores \& Standard Deviation

\begin{tabular}{ccc}
\hline Attire & $\begin{array}{c}\text { Mean } \\
\text { Score }\end{array}$ & $\begin{array}{c}\text { Stnd } \\
\text { Dev }\end{array}$ \\
\hline Khaki & 3.273 & 1.428 \\
Professional & 2.440 & 1.368 \\
Workout & 2.180 & 1.366 \\
\hline
\end{tabular}

\section{Representation}

General regression considering Gender and Attire showed $\mathrm{P}=0.751$ indicating gender did have an effect on the responses. ANOVA showed a significant effect for the group ( $F=72.76)$. The khaki attire (mean=3.847) rated highest, followed by professional (mean=2.676) and workout attire (mean=2.333) as the lowest. 
Table 4.10

Representation Mean Scores \& Standard Deviation

\begin{tabular}{ccc}
\hline Attire & $\begin{array}{l}\text { Mean } \\
\text { Score }\end{array}$ & $\begin{array}{c}\text { Stnd } \\
\text { Dev }\end{array}$ \\
\hline Khaki & 3.847 & 1.035 \\
Professional & 2.676 & 1.225 \\
Workout & 2.333 & 1.151 \\
\hline
\end{tabular}

\section{Knowledge}

General regression considering Gender and Attire showed $\mathrm{P}=0.367$ indicating no effect of gender on attire. ANOVA showed a significant difference $(F=19.55)$ between the three groups with Khaki having the highest mean score (mean=3.360). Professional attire (mean=2.693) and workout attire (mean=2.342) were not statistically different.

Table 4.11

Knowledge Mean Scores \& Standard Deviation

\begin{tabular}{ccc}
\hline Attire & $\begin{array}{l}\text { Mean } \\
\text { Score }\end{array}$ & $\begin{array}{c}\text { Stnd } \\
\text { Dev }\end{array}$ \\
\hline Khaki & 3.360 & 1.416 \\
Professional & 2.693 & 1.470 \\
Workout & 2.342 & 1.404 \\
\hline
\end{tabular}

The final question had respondents select attire they thought was appropriate for the various demands of the job. In table 4.12 the number of responses for each type of attire (Khaki 
Attire, Workout Attire, and Professional Attire) as well gender are indicated. Khaki attire was rated the highest for all work settings (daily athletic training room coverage, indoor event, and outdoor event) with the male khaki attire being the most preferred. Workout attire and professional attire were rated lower in all categories over khaki attire.

Table 4.12

Appropriate Attire Based on Coverage.

Number of Responses

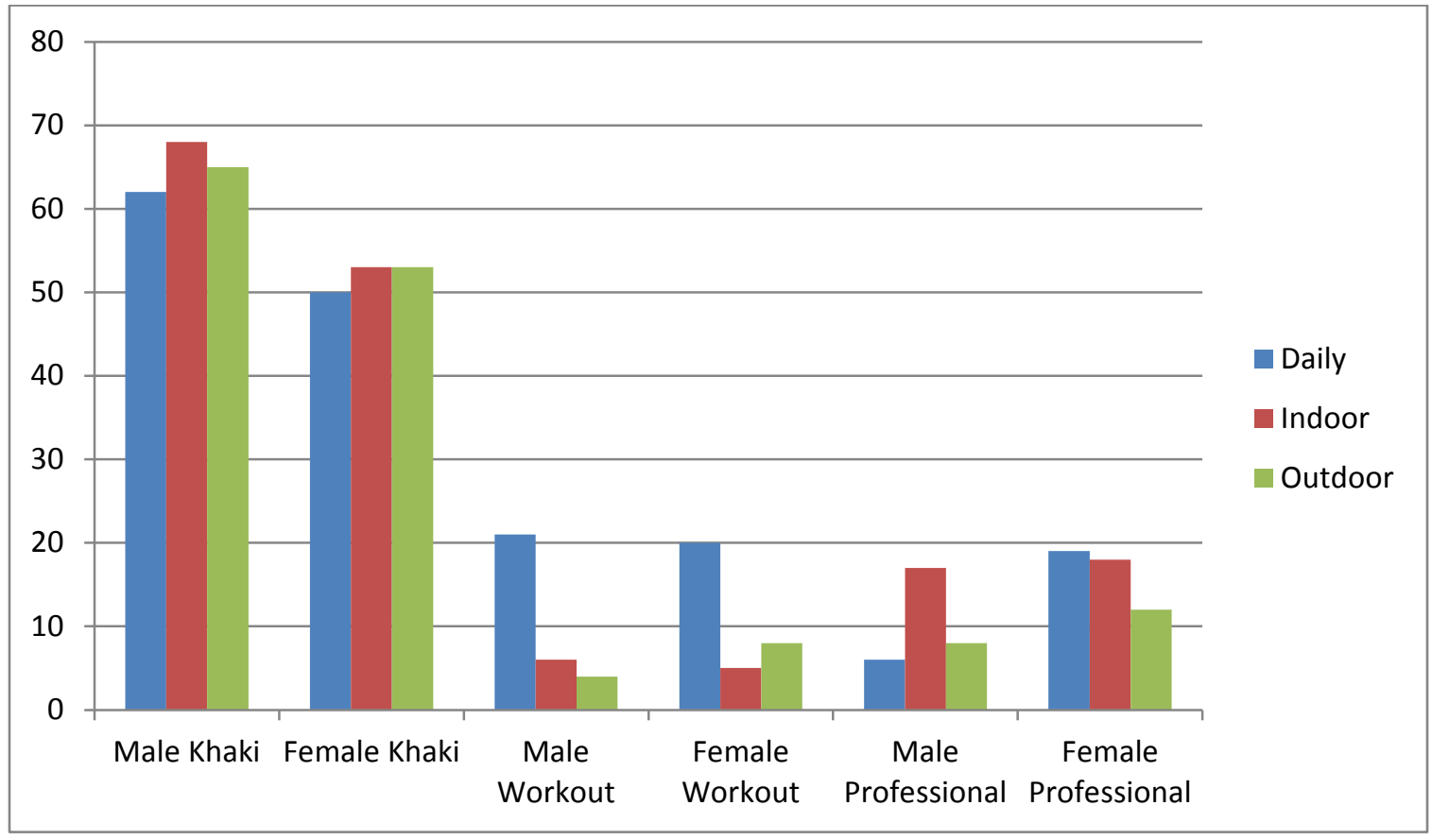




\section{Discussion}

Very little research has been done in the field of athletic training to identify how attire impacts the perceptions of knowledge and competence. Research has been conducted in the fields of, allied health care and education in an attempt to identify which types of attire result in the highest perceptions of professional knowledge and competence. Lehna, Pfoutz, Peterson, Degner, Grubaugh, Lorenz, et. al (1999) concluded that nursing attire was a way for the public to identify a nurse and patients showed preference to nurses when wearing a white uniform. Further research by Skorupski and Rea (2006) concluded that when a nurse wore a scrub uniform patients gave higher ratings of professionalism and approachability. Rehmen et.al (2005) concluded that patients have a significant preference for professional attire and have rated those in professional attire highest in perceptions of quality of care, trust, and confidence. Educators showed a significant relationship between professional attire and student cognitive learning, affective learning, and rating of instruction from college students (Roach, 1997)

This initial examination investigated how high school athletic directors’ perceptions of professional competence and knowledge were affected by attire. High school athletic directors are usually the direct supervisors to high school athletic trainers and are influential in hiring, salary, and budget, which is why they were the chosen population for this study instead of student athletes.

High school athletic directors in California randomly chosen from the CIF personnel guide were contacted by the researcher via email. To participate in the study the participants

followed a link to the questionnaire on surveymonkey.com. The beginning of the questionnaire 
helped to identify if high school athletic directors felt that accountability (mean=4.443), fair treatment of athletes (mean=4.454), punctuality (mean=4.216), confidentiality (mean=4.371), and organization (mean=4.000) were important attributes that an athletic trainer should possess. It was overwhelmingly apparent that all of these attributes were rated as being very important for athletic trainers. These results indicate attributes a quality employee and athletic trainer should possess.

Overall the results of this study identified a significant difference in perceptions of professional competence and knowledge based on type of attire. Respondents identified the highest perceptions of knowledge ( $\mathrm{K}=3.360, \mathrm{P}=2.693, \mathrm{~W}=2.342)$, experience $(\mathrm{K}=3.273$, $\mathrm{P}=2.440, \mathrm{~W}=2.180)$, overall competence $(\mathrm{K}=3.340, \mathrm{P}=2.620, \mathrm{~W}=2.300)$, skill $(\mathrm{K}=3.320$, $\mathrm{P}=2.673, \mathrm{~W}=2.327)$, and approachability $(\mathrm{K}=3.673, \mathrm{P}=3.107, \mathrm{~W}=2.183)$ when the photo was someone dressed in khaki attire. Professional attire and workout attire were rated lower than khaki attire but had no difference between each other. Respondent's rated khaki attire highest, followed by professional attire, and rated workout attire the lowest when identifying their perception of representation $(\mathrm{K}=2.676, \mathrm{P}=2.676, \mathrm{~W}=2.333)$ and level of education $(\mathrm{K}=3.300$, $\mathrm{P}=2.772, \mathrm{~W}=2.280$ ). There was interaction between gender and attire with the variables of representation, education, and overall competence which may have impacted the outcome of the ratings. At the end of the questionnaire all 6 photos were shown and the athletic directors were asked to check all appropriate attire for daily athletic training room coverage, indoor event coverage, and outdoor event coverage. Male and female in khaki attire were rated much higher for all three types of work settings over workout attire and professional attire.

Findings from this study indicate that high school athletic directors' perceptions of professional knowledge and competence are highest when an athletic trainer is wearing khaki 
and polo attire. It also appears that most athletic directors prefer khaki attire over workout and professional attire for any type of event coverage. This is different from the currently accepted attire athletic trainers wear especially at indoor events where the accepted attire is professional dress. These results recommend that appropriate attire for athletic trainers is khaki pants or shorts and a polo shirt and that this attire that may result in the highest perceptions of professional knowledge and competence as well as convey the most professional image.

Physicians, nurses, and educators indicated highest perceptions of professional skills and competence when the highest level of professional attire was seen. The results of this study vary slightly since khaki attire resulted in the highest rating over professional attire. The most likely reason for this discrepancy is that athletic trainers are also identified when wearing khaki pants or shorts and a polo shirt, therefore athletic directors may rate khaki attire higher than professional attire because that is how they identify athletic trainers.

This study had two major limitations; a small sample size and response rate (15\%) and lack of prior research. In research conducted by Baruch (2008) it was concluded that a normal response rate was 55.6\%. Since the response rate only yielded 94 useable data points the researcher was unable to perform the desired statistical analysis to address the research hypothesis. The second limitation regarding lack of prior research identifies a variety of opportunities for further research in the field of athletic training and types of attire.

There are several areas for further research that have been revealed through this study. Further research using this same design needs to be done where the researcher has a higher response rate and is able to utilize a regression analysis which will allow a correlation between attire and athletic directors' perceptions of professional knowledge and competence to be identified. 
The most apparent opportunity for further research would be to determine if khaki attire is the most appropriate attire for athletic trainers. Based on these results high school athletic directors have the highest perception of professional competence and knowledge when an athletic trainer wears khaki attire. Research done to identify why high school athletic directors prefer khaki attire should be done. Do they prefer this attire because this is what they are familiar with or this is how they identify athletic trainers, or is khaki attire what presents an athletic trainer as a competent and knowledgeable health care provider? 


\section{References}

Baruch, Y., Holtom, B.C. (2008) Survey response rate levels and trends in organizational research. Human Relations, 1139-1161.

Brase, G. L., \& Richmond, J. (2004). The white-coat effect: physician attire and perceived authority, friendliness, and attractiveness. Journal of Applied Social Psychology, 24692481.

Carr, D.L., Davies, T.L., Lavin, A. M. (2010, March 1). The impact of instructor attire on college student satisfaction. College Student Journal, V44I1

Carr-Saunders, A.W. (1966). “Professionalization in historical perspective,” in Vollmer, H.M. and Mills, D.L. (Eds), Professionalization, Prentice-Hall, Englewood Cliffs, NJ, USA.

Craig, D. I. (2006). Learning professionalism in athletic training education. Athletic Training Education Journal , 8-11.

Dodge, T., \& Mensch, J. M. (2004, November). Image is everything. Athletic Therapy Today, pp. 58-59.

Eaves, Ted (2009) The Practice Guide to Athletic Training. Ontario, Canada: Jones \&Bartlett 
Ebel, R. (1999). Far Beyond the Shoe Box Fifty Years of the National Athletic Trainers' Association. Forbes.

Gorham, J., Cohen, S. H., \& Morris, T. L. (1999). Fashion in the classroom III: effects of instructor attire and immediacy in the natural classroom nteractions. Communicaiton Quartery, 281-299.

Hammer, D. P. (2000). Professional attitudes and behaviors: The "A's and B's" of professionalism. American Journal of Pharmaceutical Education , 455-464.

Hillman, S. K. (2000). Introduction to Athletic Training. Champaign: Human Kinetics.

H.R. 1137--111th Congress: Athletic Trainers’ Equal Access to Medicare Act of 2009. (2009). In GovTrack.us (database of federal legislation). Retrieved April 13, 2012, from http://www.govtrack.us/congress/bills/111/hr1137

H.R. 2785--112th Congress: Athletic Trainers’ Equal Access to Medicare Act of 2011. (2011). In GovTrack.us (database of federal legislation). Retrieved April 13, 2012, from http://www.govtrack.us/congress/bills/112/hr2785

Jessup, D. (2004, October). Some settings demand less formal clothes. NATA News, p. 52. 
Johnson, K. K., Schofleld, N. A., \& Yurchisin, J. (2001). Appearance and dress as a source of information: A qualitative approach to data collection. Clothing and Textiles Research Journal , 125-137.

Lehna, C., Pfoutz , S., Peterson, T., Degner, K., Grubaugh, K., Lorenz, L., Mastropietro, S., et al. (1999). Nursing attire: indicators of professionalism? Journal of Professiona Nursing , 192-199.

Mensch, J. M. (2005, March). What are you wearing? Appropriate attire for certified athletic trainers. Athletic Therapy Today, pp. 52-53.

Miller, T., Mann, N., \& Grim, R. (2010). Clothes encounter: patient perception of nursing attire in a behavioral health unit. Journal of the Merican Psychiatric Nurses Association , 178183.

Morris, T. L., Gorham, J., Cohen, S. H., \& Huffman, D. (1996). Fashion in the classroom: Effects of attire on student perceptions of intructors in college classes. Communication Education , 135-147.

NATA. (2012, March). Health Care Reform Law. Retrieved April 1, 2012, from NATA.ORG: http://www.nata.org/health-care-reform 
NATA. NATA Final Comment Letter. Marje Albohm 2005. Retrieved April 14, 2011, from http://www.nata.org/members1/committees/gac/CMS/NATA_Final_Comment_Lett er.pdf

NATABOC. (2007). The BOC Exam: The First 40 Years a Tribute to our Volunteers. Omaha: Jacob North Printing Company.

Park B. (1986). A method for studying the development of impressions of real people. Journal of Personality and Social Psychology, 51(5), 907-917.

Prentice, W. E. (2003). Arnheim's Principles of Athletic Training A competency-based approach. New York: McGraw-Hill.

Prentice, W.E. (2011). Principles of Athletic Training. New York: McGraw-Hill.

Ray, R. (2000). Management Strategies in Athletic Training. Champaigne: Human Kinetics.

Rehman, S. U., Nietert, P. J., Cope, D. W., \& Lipatrick, A. O. (2005). What to wear today? Effect of doctor's attire on trust and confidence of patients. American Journal of Medicine , 1279-1286. 
Roach, D. K. (1997). Effects of graduate teaching assistant attire on student learning, misbehaviors, and ratings of instructions. Communication Quarterly, 125-141.

Roach-Higgins, M.E., \& Eicher, J.B. (1992). Dress and identity. Clothing and Textiles Research Journal, 10(4), 1-8.

Skorupski, V.J., Rea, R. E., (2006). Patients’ perceptions of today’s nursing attire: Exploring dual images. Journal of Nursing Administration 36(9), 393-401.

Thomas, C.M, Ehret, A., Ellis, B., Colon-Schoop, S., Linton, J., Metz, S. (2010). Perception of nurse caring, skills, and knowledge based on appearance. Journal of Nursing Administration, 40(11), 489-497.

Vruggink, M., \& Green, A. (2002, June). Professional image: How are we being perceived. NATA News , p. 48.

West, M. (2004, August). The world is watching. NATA News , p. 42. 


\section{APPENDIX A}

Human Subjects

INFORMED CONSENT TO PARTICIPATE IN High School Athletic Directors Perceptions of an Athletic Trainer's Professional Skills Based on Attire.

A research project on perceptions and attire is being conducted by Raechel Cunningham in the Department of Kinesiology at Cal Poly, San Luis Obispo. The purpose of the study is to determine if there is a relationship between attire and perceptions of professional skills.

You are being asked to take part in this study by completing the attached/enclosed questionnaire. You will click on the link included in this email and be directed to the questionnaire. You will then complete the questionnaire and the results will be sent directly to the researchers. Your participation will take approximately fifteen minutes. Please be aware that you are not required to participate in this research and you may discontinue your participation at any time without penalty. You may also omit any items on the questionnaire you prefer not to answer.

There are no possible risks associated with participation in this study. However, you should experience any adverse psychosocial affects please be aware that you may contact Cal Poly Health Counseling Services at (805) 756-2511 for assistance.

Your responses will be provided anonymously to protect your privacy. Potential benefits associated with the study include a more in depth understanding of the between athletic trainers attire and its relationship to the perceived professional skills from high school athletic directors.

If you have questions regarding this study or would like to be informed of the results when the study is completed, please feel free to contact Raechel Cunningham at 805-756-1786 . If you have questions or concerns regarding the manner in which the study is conducted, you may contact Dr. Steve Davis, Chair of the Cal Poly Human Subjects Committee, at 756-2754, sdavis@calpoly.edu, or Dr. Susan Opava, Dean of Research and Graduate Programs, at 7561508, sopava@calpoly.edu.

If you agree to voluntarily participate in this research project as described, please indicate your agreement by continuing to the questionnaire by clicking on the link included in the email. Please retain this consent cover form for your reference. 


\section{APPENDIX B}

Questionnaire

\section{Ethnographic Data}

1. Age: $21-25$ 26-30 31-35 36-40 41-45 46-50 51-55 56-60

2. Sex: $M / F$

3. Education:

- $\quad$ Some College

- Associate Degree

- Bachelors Degree

- Graduate Degree

- Post Graduate Degree

4. Years employed at current district: $(0-3)(4-8)(9-11)$ (12 or more)

5. Does your school have a full time athletic trainer? _YES/NO

6. Is your athletic trainer (please check)

Part Time

Full Time

Contracted from another source

7. Please rate the professional behaviors and attitudes you feel an athletic trainer should possess (Very Important, somewhat important, not important)

Not Important Neutral Very Important

$\begin{array}{llllll}\text { Accountability } & 1 & 2 & 3 & 4 & 5 \\ \text { Fair Treatment of all athletes } & 1 & 2 & 3 & 4 & 5\end{array}$




$\begin{array}{llllll}\text { Punctual } & 1 & 2 & 3 & 4 & 5 \\ \text { Maintains confidentiality } & 1 & 2 & 3 & 4 & 5 \\ \text { Organized } & 1 & 2 & 3 & 4 & 5\end{array}$

8. Please rate this athletic trainers on your perception of (Insert photo's of attire)

Lowest level Moderate Highest Level

$\begin{array}{llllll}\text { Skills } & 1 & 2 & 3 & 4 & 5 \\ \text { Knowledge } & 1 & 2 & 3 & 4 & 5 \\ \text { Approachability } & 1 & 2 & 3 & 4 & 5 \\ \text { Experience } & 1 & 2 & 3 & 4 & 5 \\ \text { Overall Competence } & 1 & 2 & 3 & 4 & 5 \\ \text { Education Level } & 1 & 2 & 3 & 4 & 5\end{array}$

9. Please rate this athletic trainers on your perception of the following (Insert photo's)

\begin{tabular}{|c|c|c|c|c|c|}
\hline \multirow[b]{2}{*}{ Confidence in diagnosis and treatment } & \multicolumn{2}{|c|}{ Lowest Level } & \multirow{2}{*}{$\begin{array}{l}\text { Moderate } \\
3\end{array}$} & \multicolumn{2}{|r|}{ Highest Level } \\
\hline & 1 & 2 & & 4 & 5 \\
\hline Experience & 1 & 2 & 3 & 4 & 5 \\
\hline Reliability & 1 & 2 & 3 & 4 & 5 \\
\hline Ability to relate to coaches & 1 & 2 & 3 & 4 & 5 \\
\hline Ability to relate to athletes & 1 & 2 & 3 & 4 & 5 \\
\hline
\end{tabular}


Ability to relate to parents

Ability to relate to administration

\begin{abstract}
1
\end{abstract}

$\begin{array}{llll}2 & 3 & 4 & 5\end{array}$

$\begin{array}{lllll}1 & 2 & 3 & 4 & 5\end{array}$

10. Which of the attire do you think is appropriate for an athletic trainer to wear for (check all that apply) (\#1-6) (Insert Photo's)

Daily Athletic Training room and practice coverage?

Indoor event coverage (basketball game, volleyball game)

Outdoor Event coverage (football game, baseball game etc.) 